\title{
EPSL
}

Earth and Planetary Science Letters 125 (1994) 55-70

\section{Fluid transfer in anorthosites and related rocks from Rogaland (Southwest Norway): Evidence from stable isotopes}

\author{
E. Wilmart ${ }^{\mathrm{a}, 1}$, F. Pineau ${ }^{\mathrm{a}}$, A. Réjou-Michel ${ }^{\mathrm{a}}$, J.C. Duchesne ${ }^{\mathrm{b}}$ \\ ${ }^{a}$ Laboratoire de Géochimie des Isotopes Stables, Tour 54 /64, Université de Paris VII, IPGP, URA 196, 2 place Jussieu, \\ F-75251 Paris Cedex 05, France \\ b Laboratoires associés Géologie, Pétrologie, Géochimie, Université de Liège, B20, B-4000 Sart-Tilman, Belgium
}

Received 19 April 1993; revision accepted 16 May 1994

\begin{abstract}
$\mathrm{C}$ and $\mathrm{H}$ contents and $\mathrm{C}, \mathrm{H}$ and $\mathrm{O}$ isotopic compositions have been measured in sixteen samples of the Åna-Sira massif-type anorthosite (Rogaland, Southwest Norway) and in 30 surrounding rocks, including the metamorphic envelope and magmatic intrusions related to the anorthosite emplacement.

Oxygen isotopic compositions of the Ana-Sira anorthositic massif $\left(\delta^{18} \mathrm{O}=6.1 \pm 0.3 \%\right.$ ) and the Tellnes orebody $\left(\delta^{18} \mathrm{O}=5.2 \pm 0.2 \%\right.$ ) are consistent with a pure mantle origin and show no evidence for exchange with hydrothermal fluids. The associated rocks (norites to charnockites) have $\delta^{18} \mathrm{O}$ values $(5.2 \pm 0.9 \%$ ) similar to uncontaminated mantle-derived magmas.

The $\mathrm{H}_{2} \mathrm{O}$ content of the rocks (magmatic or metamorphic) is lower than $0.54 \%$, suggesting the preservation of original granulite facies conditions during cooling and uplift.

Due to their cumulate origin, the anorthosites are very poor in carbon (bulk $\mathrm{C}<50 \mathrm{ppm}$ ), the volatiles having been concentrated in the residual melt. Higher carbon concentrations (up to $1484 \mathrm{ppm}$ ) are found in the associated intrusions. Anorthosites and gneisses close to the contacts (less than $500 \mathrm{~m}$ ) with later intrusions show an increase in their carbon content (up to $700 \mathrm{ppm} \mathrm{C}$ ), and this carbon is mainly in the form of interstitial carbonate.

The carbon distribution observed at the contact between later intrusions and anorthosites as well as gneisses indicates that some $\mathrm{CO}_{2}$ has fluxed from the later magmas over a distance of a few hundred metres. This suggests only minimal lateral propagation of the fluids by diffusion or infiltration. Tentative carbon budgets suggest that most of the volatiles were transferred upwards into the overlying continental crust.
\end{abstract}

\section{Introduction}

The origin and role of $\mathrm{CO}_{2}$ in granulite facies metamorphism has been the subject of much de-

\footnotetext{
[CL]

${ }^{1}$ Present address: CNRS, Service des Relations Industrielles, avenue de la Terrasse, F-91198 Gif-sur-Yvette, France
}

bate. Some authors $[1-3$, and references therein] suggest that granulite metamorphism is due to $\mathrm{CO}_{2}$ streaming, while Lamb and Valley [4] invoke recrystallization of originally dry rocks. Frost and Frost [5] developed a model which emphasised the role of basaltic melts intruded into the crust. Such melts would be capable of assimilating $\mathrm{H}_{2} \mathrm{O}$ from the lower crust and would also be the source 
of $\mathrm{CO}_{2}$. This concept has been recently illustrated by several authors [6-8].

Although the origin of massif-type anorthosites is still unclear, most workers [9-11] agree with a two-stage formation: crystallisation at or near the mantle-crust boundary followed by emplacement at a shallower level. The envelope of the anorthosites is usually metamorphosed in the granulite facies. In Rogaland, a large-scale aureole of granulite facies metamorphism has been induced by the emplacement of anorthosites and related rocks $[12,13]$.

We investigate here the role of these magmas as a source of $\mathrm{CO}_{2}$ in the granulite metamorphism in the Rogaland Province by using stable isotopes to constrain the fluid phase degassed by mantle-derived magmas intruded at the mantlecrust boundary, in an approach similar to that developed for tholeiitic magmas by Javoy et al. [14] and Gerlach and Taylor [15].

Carbon, oxygen and hydrogen isotopic compositions have been measured in whole-rock anorthosites and plagioclase phenocrysts from several localities of the Ana-Sira massif and in whole rocks from the surrounding intrusions and gneisses. Oxygen isotopic compositions have been determined to assess the importance of crustal contamination in the various magmatic units and to study possible exchange between rocks and fluids. The pattern of carbon contents in the anorthosites and surrounding rocks has been established in order to trace the importance of C-rich fluid migration.

\section{Geological setting}

The Ana-Sira massif (AS) is one of the three large anorthosite bodies constituting the Rogaland Igneous Province. Petrographically, the anorthosite is monotonous and comprises granulated, equal-sized $(1-3 \mathrm{~cm})$, homogeneous plagioclase $\left(\mathrm{An}_{40-50}\right)$. Locally, it contains aggregates of $\mathrm{Al}$-rich orthopyroxene and plagioclase megacrysts. The samples were collected using the geological map of Krause and Pedall [16]. The only C-rich species which can be recognised are rare carbon- ate microcrysts located in plagioclase cracks and intergrains. $\mathrm{CO}_{2}$-rich fluid inclusions and graphite crystals have never been found, although petrographic observations cannot exclude the occurrence of submicroscopic graphite particles. An altered sample, whitish in colour and somewhat saussuritized, has also been studied (sample 8, see below).

The AS massif is quite similar to the Egersund-Ogna (EGOG) massif studied by Michot [17] and Maquil and Duchesne [18]. The latter proposed a two-stage petrogenesis: crystallisation around 12-15 kbar and a final emplacement as a crystal mush in granulite facies $P-T$ conditions (around 6-8 kbar, [19]). The isotopic data on the EGOG massif $\left(I_{\mathrm{Sr}}=0.703-\right.$ $0.705 ; \epsilon_{\mathrm{Nd}}=+3.7$ to +4.6 ) suggest an origin in the depleted upper mantle [20].

The AS massif intruded a series of gneisses of supracrustal origin [21]. The AS anorthosite has been intruded by the layered Bjerkreim-Sokndal (BKSK) intrusion, which comprises cumulates and melts of the whole anorthosite-charnockite (= hypersthene granite) suite [22, and references therein], and mangerites (= hypersthene monzonites) and jotunites (= hypersthene diorites), forming the so-called Apophysis. The latter massif intruded between the AS massif and its envelope of metamorphic gneisses. The AS massif is cross-cut by an ilmenite norite lens (the Tellnes orebody) extending into a jotunitic to charnockitic dyke called the Tellnes dyke [16]. The orebody has been interpreted as a cumulate probably formed in a liquid related to the AS anorthosite [23]. On the other hand, the parental magma of the Tellnes dyke has an initial strontium isotope ratio of 0.7069 , pointing to the assimilation of crustal components [23].

The entire Rogaland Igneous Province was emplaced in a relatively short time, between 929 $\pm 2 \mathrm{Ma}$ for the EGOG intrusion and $920 \pm 2 \mathrm{Ma}$ for the Tellnes orebody (U-Pb zircon ages, [24]). The anorthosites and associated rocks are thus cogenetic.

Contrary to that known in the Adirondack Mountains, no later metamorphic overprinting has ever been recognised in Rogaland. This characteristic, initially deduced from field and petro- 
graphic arguments, has been confirmed recently by U-Pb studies: the last tectonic event occurred around $1000 \mathrm{Ma}$, which is ca. $70 \mathrm{Ma}$ before the anorthosite emplacement [24]. Both the emplacement of the anorthosites (and related rocks) in the granulite facies conditions and the absence of

Table 1

Carbon and oxygen isotopic data for the Ana-Sira anorthosites, the surrounding intrusions and the metamorphic gneisses. Data corrected for blank and adsorption values. WR $=$ whole rock

\begin{tabular}{|c|c|c|c|c|c|c|c|}
\hline Sample & Rock type & $\begin{array}{l}\text { Bulk C } \\
\text { (ppm) }\end{array}$ & $\begin{array}{c}\text { Bulk } \boldsymbol{\delta}^{13} \mathrm{C} \\
(\% \circ)\end{array}$ & $\begin{array}{c}\text { Carbonate } \\
\text { (ppm C) }\end{array}$ & $\begin{array}{l}\text { Carbonate } \\
\delta^{13} \mathrm{C}(\% \circ)\end{array}$ & $\begin{array}{l}\text { Carbonate } \\
\delta^{180}(\% \circ)\end{array}$ & $\underset{\left(\mathscr{W}_{0}\right)}{\mathbf{W R} \delta^{18} \mathrm{O}}$ \\
\hline $\begin{array}{l}\text { ANA-SIRA MAS } \\
1 / 91.31 \\
2 / 91.30 \\
3 / 91.29 \\
4 / 91.28 \\
5 / 91.27 \\
6 / 91.26 \\
7 / 91.20 \\
8 / 91.22 \\
9 / 91.17 \\
10 / J C D 66.131 \\
11 / J C D 66.132 \\
12 / 91.6 \\
13 / 91.8 \\
14 / 91.24 \\
15 / 91.1 \\
16 / 91.23\end{array}$ & $\begin{array}{l}\text { Plagioclase megacryst } \\
\text { anorthosite } \\
\text { anorthosite } \\
\text { anorthosite } \\
\text { anorthosite } \\
\text { plagioclase megacryst } \\
\text { anorthosite } \\
\text { anorthosite } \\
\text { plagioclase megacryst } \\
\text { plagioclase megacryst } \\
\text { plagioclase megacryst } \\
\text { plagioclase megacryst } \\
\text { anorthosite } \\
\text { anorthosite } \\
\text { anorthosite } \\
\text { anorthosite }\end{array}$ & $\begin{array}{c}20 \\
29 \\
\leq 10 \\
113 \\
\leq 10 \\
19 \\
\leq 10 \\
\leq 10 \\
43 \\
294 \\
444 \\
104 \\
790 \\
161 \\
100 \\
103\end{array}$ & $\begin{array}{c} \\
-20.4 \pm 0.8 \\
-14.0 \\
-5.4 \\
-4.9 \\
-4.8 \\
-5.6 \\
-6.1 \\
-11.8\end{array}$ & $\begin{array}{c}7.7 \pm 0.1 \\
72 \\
183 \\
59 \\
718 \\
156 \\
96 \\
77\end{array}$ & $\begin{array}{l}-7.4 \pm 0.4 \\
-5.2 \\
-4.1 \\
-7.2 \\
-4.2 \\
-4.5 \\
-5.9 \\
-6.2\end{array}$ & $\begin{array}{c}13.4 \pm 1.3 \\
9.4 \\
8.9 \\
9.9 \\
10.5 \\
15.0 \\
12.0 \\
15.6\end{array}$ & $\begin{array}{c}6.1 \pm 0.2 \\
6.0 \\
5.9 \pm 0.1 \\
6.7 \pm 0.1 \\
5.9 \\
6.2 \\
5.7 \\
6.4 \pm 0.1 \\
6.1 \pm 0.4 \\
5.9 \pm 0.2 \\
5.9 \pm 0.1 \\
6.5 \\
6.1 \pm 0.0 \\
5.9 \\
5.8 \pm 0.0 \\
6.4 \pm 0.1\end{array}$ \\
\hline $\begin{array}{l}\text { TELLNES OREI } \\
17 / 66.262 \\
18 / 66.263 \\
19 / 64.145 \\
20 / 91.5 \\
21 / 121 \\
22 / 91.10 \\
23 / 91.10\end{array}$ & $\begin{array}{l}\text { ODY } \\
\text { ilmenite norite } \\
\text { ilmenite norite } \\
\text { ilmenite norite } \\
\text { fine-grained norite } \\
\text { leuconorite } \\
\text { late carbonates } \\
\text { late quartz }\end{array}$ & $\begin{array}{c}894 \pm 45 \\
395 \\
582 \\
1026 \\
410\end{array}$ & $\begin{array}{c}-4.1 \pm 0.0 \\
-4.0 \\
-5.4 \\
-4.0 \\
-6.2\end{array}$ & $\begin{array}{c}603 \\
437 \\
288 \\
1069 \\
251\end{array}$ & $\begin{array}{l}-2.6 \\
-3.0 \\
-3.5 \\
-4.3 \\
-5.6 \\
-5.0\end{array}$ & $\begin{array}{l}13.0 \\
12.5 \\
17.5 \\
19.5 \\
11.9 \\
7.8\end{array}$ & $\begin{array}{c}5.1 \pm 0.1 \\
5.4 \pm 0.2 \\
5.1 \pm 0.2(3) \\
4.9 \\
6.0 \pm 0.1 \\
10.6 \pm 0.1\end{array}$ \\
\hline $\begin{array}{l}\text { TELLNES DYK } \\
24 / 72.52 \\
25 / 78.28 \\
26 / 78.32 \\
27 / 84.9\end{array}$ & $\begin{array}{l}\text { jotunite } \\
\text { mangerite } \\
\text { charnockite } \\
\text { charnockite }\end{array}$ & $\begin{array}{c}980 \\
1484 \\
440 \\
564\end{array}$ & $\begin{array}{l}-8.5 \\
-7.3 \\
-21.5 \\
-10.5\end{array}$ & $\begin{array}{c}410 \\
841 \\
40 \\
376\end{array}$ & $\begin{array}{l}-5.3 \\
-4.9 \\
-0.6 \\
-7.0\end{array}$ & $\begin{array}{c}1.1 \\
9.4 \\
14.8 \\
9.4\end{array}$ & $\begin{array}{l}5.0 \pm 0.1 \\
5.3 \pm 0.1 \\
6.5 \pm 0.3 \\
6.0 \pm 0.2\end{array}$ \\
\hline $\begin{array}{l}\text { BJERKREIM-SC } \\
\text { 28/JCD64.23 } \\
\text { 29/JCD66.102 } \\
\text { 30/JCD80.23.1 } \\
\text { 31/JCD80.14.7B } \\
\text { 32/JCD80.14.6C } \\
\text { 33/JCD80.14.6B } \\
\text { 34/T II }\end{array}$ & $\begin{array}{l}\text { KNDAL LOPOLITH } \\
\text { troctolite } \\
\text { apatite norite } \\
\text { apatite norite } \\
\text { mafic-rich norite } \\
\text { mangerite } \\
\text { mafic-rich norite } \\
\text { mangerite }\end{array}$ & $\begin{array}{c}335 \\
1080 \\
1211 \\
176 \\
222 \pm 12 \\
75 \\
336\end{array}$ & $\begin{array}{c}-7.0 \\
-5.3 \\
-4.6 \\
-19.2 \\
-7.2 \pm 0.2 \\
-18.0 \\
-15.9\end{array}$ & $\begin{array}{l}267 \\
470 \\
937 \\
<10 \\
<10 \\
<10 \\
159\end{array}$ & $\begin{array}{l}-2.8 \\
-3.4 \\
-3.4 \\
\\
\\
-2.6\end{array}$ & $\begin{array}{l}16.6 \\
16.8 \\
11.1 \\
\\
12.6\end{array}$ & $\begin{array}{c}5.8 \pm 0.1 \\
5.0 \pm 0.1 \\
5.6 \\
4.2 \pm 0.1 \\
6.0 \\
3.3 \pm 0.5 \\
5.5\end{array}$ \\
\hline $\begin{array}{l}\text { APOPHYSIS } \\
\text { 35/JCD81.12.8.1 } \\
\text { 36/JCD81.12.8.2 }\end{array}$ & $\begin{array}{l}\text { fine-grained jotunite } \\
\text { porphyritic mangerite }\end{array}$ & $\begin{array}{c}1088 \\
364\end{array}$ & $\begin{array}{l}-4.1 \\
-3.8\end{array}$ & $\begin{array}{l}436 \\
437\end{array}$ & $\begin{array}{l}-3.4 \\
-1.8\end{array}$ & $\begin{array}{l}12.2 \\
13.5\end{array}$ & $\begin{array}{c}4.9 \pm 0.2 \\
4.5\end{array}$ \\
\hline $\begin{array}{l}\text { METAMORPHI } \\
\text { 37/81.27.1D } \\
38 / J C D 72.18 \\
39 / 81.12 .16 \\
40 / 73.50 \mathrm{~B} \\
41 / 73.50 \mathrm{~A} \\
42 / 81.12 .11 \\
43 / 81.16 .1 \\
44 / 81.12 .1 \mathrm{~A} \\
45 / 81.15 .1\end{array}$ & $\begin{array}{l}\text { ENVELOPE } \\
\text { granitic gneiss } \\
\text { qtz mangeritic gneiss } \\
\text { qtz monzonoritic augen gneiss } \\
\text { alaskite } \\
\text { noritic gneiss } \\
\text { noritic gneiss } \\
\text { noritic gneiss } \\
\text { kinzigitic gneiss } \\
\text { granitic gneiss }\end{array}$ & $\begin{array}{c}\leq 20 \\
225 \\
81 \\
1077 \\
598 \\
501 \\
202 \\
62 \pm 3 \\
178 \pm 83\end{array}$ & $\begin{array}{c}-12.0 \\
-5.7 \\
-18.6 \\
-4.5 \\
-5.5 \\
-22.4 \\
-13.5 \pm 0.0 \\
-15.1 \pm 0.1\end{array}$ & $\begin{array}{c}4 \\
107 \\
71 \\
350 \\
203 \\
363 \\
24 \\
5 \\
49\end{array}$ & $\begin{array}{l}-6.1 \\
-4.4 \\
-6.7 \\
-5.0 \\
-4.3 \\
-3.7 \\
-9.2 \\
-9.0\end{array}$ & $\begin{array}{l}20.7 \\
7.5 \\
15.6 \\
7.4 \\
10.2 \\
12.0 \\
12.6 \\
15.8\end{array}$ & $\begin{array}{c}9.0 \\
4.3 \\
5.6 \\
8.7 \\
6.5 \\
5.7 \pm 0.2 \\
2.0 \pm 0.1 \\
8.2 \\
8.2\end{array}$ \\
\hline $\begin{array}{l}\text { ANATECTIC G } \\
46 / 81.24\end{array}$ & $\begin{array}{l}\text { ANITE } \\
\text { charnockite }\end{array}$ & 487 & -7.6 & 222 & -3.1 & 7.0 & $4.1 \pm 0.1$ \\
\hline
\end{tabular}


later metamorphic overprinting are essential arguments in the present study.

\section{Analytical methods}

Bulk carbon contents were obtained by reacting $0.5 \mathrm{~g}$ of powder with $\mathrm{CuO}$ in sealed quartz tubes at $1000^{\circ} \mathrm{C}$ for $12 \mathrm{~h}$. Experiments performed on $0.5 \mathrm{~g}$ of powdered carbon-free synthetic glass gave carbon contents of $40 \pm 6 \mathrm{ppm}$ at $-25 \pm$ $0.5 \%, 10 \pm 3 \mathrm{ppm}$ being from the procedure blank value and the remaining $30 \pm 5 \mathrm{ppm}$ being due to adsorption. For hydrogen, $0.5 \mathrm{~g}$ of wholerock powder, outgassed overnight at $200^{\circ} \mathrm{C}$, was heated at $1200 \pm 100^{\circ} \mathrm{C}$ until complete extraction

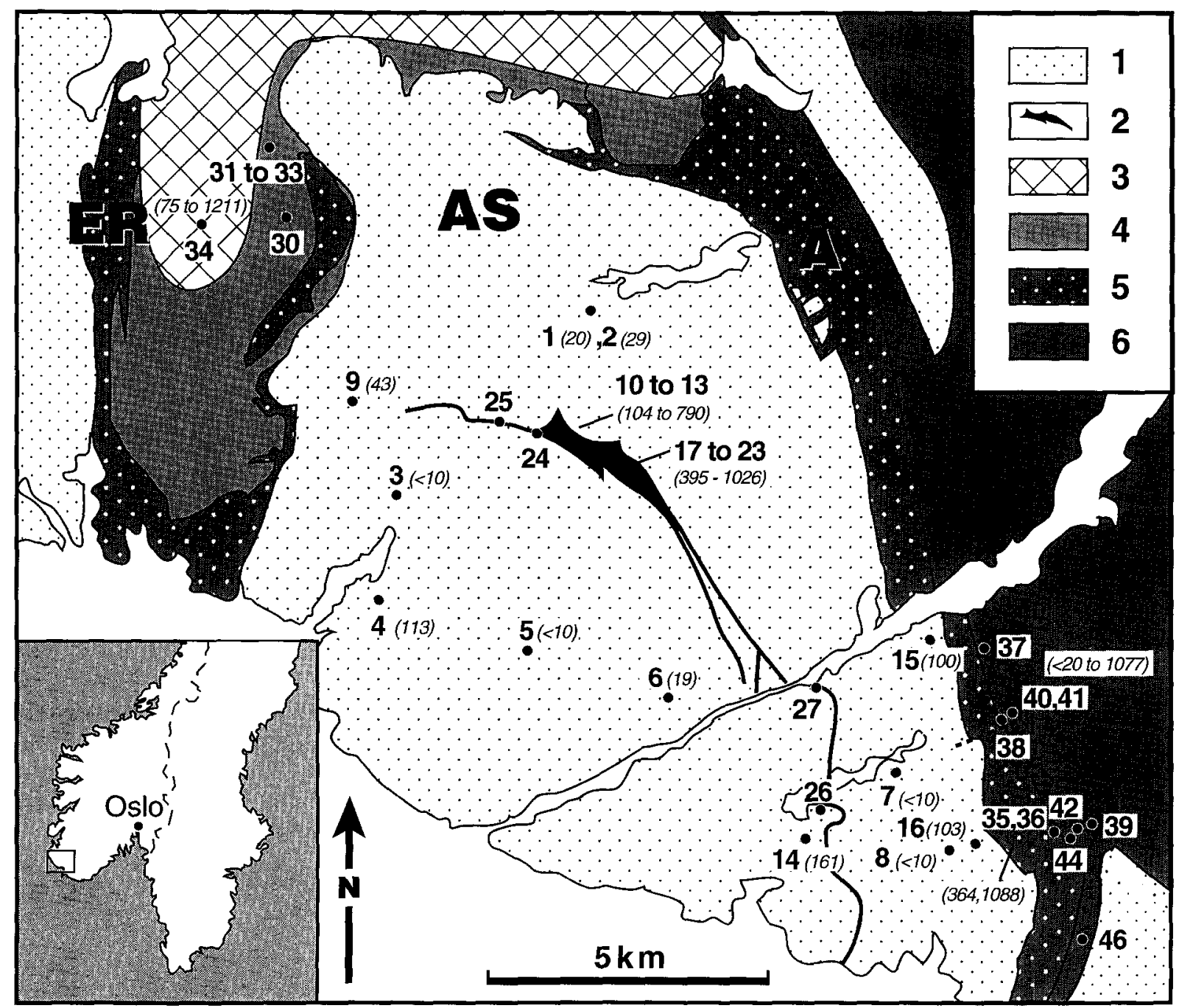

Fig. 1. Location of samples in the Åna-Sira massif and surrounding rockss. Four samples are located off the map (28 at LK338919, 29 at LK359924, 43 at LK595606 and 45 at LK605618; see sample numbers in Table 1). The figures in parentheses are the bulk carbon contents $(\mathrm{ppm})$ of the anorthosite samples. $I=$ Massif-type anorthosites and leuconorites: $A S=\AA$ Ana-Sira massif, $G=$ Garsaknat massif. 2 = Ilmenite norites and jotunites to quartz mangerites of the Tellnes orebody and dyke; $3=$ mangerites and quartz mangerites of the Bjerkreim-Sokndal intrusion; 4 =layered norites of the Bjerkreim-Sokndal (BKSK) intrusion; $5=$ jotunites and mangerites of the Eia-Rekefjord $(E R)$ and the Apophysis $(A) ; \sigma=$ gneisses from the envelope [after 16]. 
of the volatiles occurred. Apart from the anorthosites, all the samples melted. The resulting water was reduced to $\mathrm{H}_{2}$ by uranium metal at $800^{\circ} \mathrm{C}$, in readiness for isotopic analysis. The carbonates were decomposed with $\mathrm{H}_{3} \mathrm{PO}_{4}$ at $100^{\circ} \mathrm{C}$ for $1 \mathrm{~h}$ and their $\delta^{18} \mathrm{O}$ values were corrected using the fractionation factor of Rosenbaum and Sheppard [25]. Oxygen isotopes from whole rocks and minerals were extracted following the methods of Clayton and Mayeda [26] using $\mathrm{BrF}_{5}$. Two step-heating combustion experiments were performed following the experimental conditions described in Wilmart et al. [27]. All the results are expressed in the conventional $\delta$ units (relative to PDB for carbon and SMOW for oxygen and hydrogen).

\section{Results}

\subsection{The Ana-Sira massif}

All samples of anorthosite and plagioclase megacryst, whatever their position in the massif, show a restricted range of variation of $\delta^{18} \mathrm{O}$ (between 5.7 and $6.7 \%$ (samples 1 to 16 , Table 1 ), with an average value of $6.1 \pm 0.3 \%$ ).

Fig. 1 shows that, except for sample 4, all anorthosites and plagioclase megacrysts taken far $(>500 \mathrm{~m}$ ) from the contacts with the surrounding massifs and the contacts with the Tellnes orebody and dyke (samples 1 to 9) show a low bulk carbon content ( $<50 \mathrm{ppm}$, Table 1). Due to the low $\mathrm{C}$ contents, the isotopic composition was only determined for plagioclase megacryst $9(43 \mathrm{ppm} \mathrm{C})$, where $\delta^{13} \mathrm{C}$ is $-20.4 \%$.

The water contents and isotopic compositions of some of the anorthosites and plagioclase megacrysts are reported in Table 2. Except for sample 8 , which is slightly weathered and shows a larger water content $(0.69 \%)$ with $\delta \mathrm{D}=$ $-53.6 \%$, all the samples have a restricted water content of between 0.12 and $0.36 \% \mathrm{H}_{2} \mathrm{O}$, with $\delta \mathrm{D}$ values ranging from -62.6 to $-74.9 \%$. No variation in water content and $\delta \mathrm{D}$ was observed with position in the massif.

Anorthosites and plagioclase megacrysts collected close to the Tellnes orebody/dyke (samples 10 to 14, Table 1 and Fig. 1) and the Apoph-
Table 2

Hydrogen isotopic data for the Ana-Sira anorthosites and the surrounding rocks. WR $=$ whole rock

\begin{tabular}{|c|c|c|c|}
\hline Sample & Rock type & $\begin{array}{c}\text { Bulk } \mathrm{H}_{2} \mathrm{O} \\
(\%)\end{array}$ & $\underset{(\% 0)}{\text { Bulk } \delta \mathrm{D}}$ \\
\hline $\begin{array}{l}\text { ANA-SIRA M } \\
1 / 91.31 \\
3 / 91.29 \\
8 / 91.22 \\
10 / \text { CD } 66.132 \\
12 / 91.8\end{array}$ & $\begin{array}{l}\text { ASSIF } \\
\text { plagioclase megacryst } \\
\text { anorthosite } \\
\text { anorthosite } \\
\text { plagioclase megacryst } \\
\text { anorthosite }\end{array}$ & $\begin{array}{l}0.12 \\
0.36 \\
0.69 \\
0.29 \\
0.34\end{array}$ & $\begin{array}{r}-69.6 \\
-62.6 \\
-53.6 \\
-74.9 \\
-65.0\end{array}$ \\
\hline $\begin{array}{l}\text { TELLNES O } \\
17 / 66.262 \\
21 / 121\end{array}$ & $\begin{array}{l}\text { EBODY } \\
\text { ilmenite norite } \\
\text { leuconorite }\end{array}$ & $\begin{array}{l}0.25 \\
0.53\end{array}$ & $\begin{array}{r}-76.6 \\
-66.9\end{array}$ \\
\hline $\begin{array}{l}\text { TELLNES D } \\
24 / 72.52 \\
25 / 78.28\end{array}$ & $\begin{array}{l}\text { KE } \\
\text { jotunite } \\
\text { mangerite }\end{array}$ & $\begin{array}{c}0.23 \pm 0.02 \\
0.29\end{array}$ & $\begin{array}{c}-81.8 \pm 1.0 \\
-87.8\end{array}$ \\
\hline $\begin{array}{l}\text { BJERKREIM } \\
\text { 28/JCD } 64.23 \\
34 / T \text { II }\end{array}$ & $\begin{array}{l}\text { SOKNDAL LOPOLITH } \\
\text { troctolite } \\
\text { mangerite }\end{array}$ & $\begin{array}{l}0.26 \\
0.26\end{array}$ & $\begin{array}{l}-62.1 \\
-90.1\end{array}$ \\
\hline $\begin{array}{l}\text { APOPHYSIS } \\
35 / \mathrm{JCD} 81.12 .8\end{array}$ & fine-grained jotunite & 0.17 & -73.1 \\
\hline $\begin{array}{l}\text { METAMORP } \\
39 / 81.12 .16 \\
43 / 81.16 .1\end{array}$ & $\begin{array}{l}\text { HIC ENVELOPE } \\
\text { qtz monzonoritic gneiss } \\
\text { noritic gneiss }\end{array}$ & $\begin{array}{l}0.43 \\
0.54\end{array}$ & $\begin{array}{l}-69.0 \\
-69.2\end{array}$ \\
\hline $\begin{array}{l}\text { ANATECTIC } \\
46 / 81.24\end{array}$ & $\begin{array}{l}\text { GRANITE } \\
\text { chamockite }\end{array}$ & 0.17 & -75.4 \\
\hline ACTUAL ME & [EORITIC WATER & & -35.2 \\
\hline
\end{tabular}

ysis (samples 15 and 16) are richer in bulk carbon than samples collected away from the contacts. Their bulk carbon contents are as high as 790 ppm C. The bulk carbon isotopic compositions show large variations, from $\delta^{13} \mathrm{C}=-14.0$ to $-4.8 \%$. These isotopic values are not correlated with rock or megacryst bulk carbon contents, but become less negative with an increasing proportion of carbonates (from 25 to $96 \%$ of the bulk carbon content, Table 1). The mean $\delta^{13} \mathrm{C}$ and $\delta^{18} \mathrm{O}$ values of the carbonate extracted by acid attack are $-5.6 \pm 1.3 \%$ and $12.1 \pm 0.9 \%$ (Table 1) respectively. The weighted mean bulk $\delta^{13} \mathrm{C}$ value is $-7.2 \% 0$ if we consider all AS samples and $-6.8 \% 0$ if we only take the border samples. These values are close to the mean $\delta^{13} \mathrm{C}$ of the carbonates $(-5.6 \pm 1.3 \% 0)$ and show that this C-rich species is predominant.

A step-heating combustion experiment performed on a plagioclase megacryst (sample 10 , Table 3 and Fig. 2a) shows that $\sim 50 \%$ of the bulk carbon (124 ppm) is derived from the de- 
Table 3

Carbon concentrations (ppm by weight) and $\delta^{13} \mathrm{C}$ values obtained by step-heating combustion of samples 10 and 18

\begin{tabular}{lcc}
\hline Sample \# 10 & & \\
2.001 g, powder & & \\
$\mathrm{T}\left({ }^{\circ} \mathrm{C}\right)$ & $\mathrm{C}(\mathrm{ppm})$ & $\delta^{13} \mathrm{C}(\% \%)$ \\
500 & $65 \pm 1$ & $-25.9 \pm 0.1$ \\
800 without $\mathrm{O}_{2}$ & $124 \pm 1$ & $-8.7 \pm 0.1$ \\
1000 & $29.6 \pm 0.3$ & $-22.7 \pm 0.1$ \\
1200 & $13.4 \pm 0.1$ & $-13.7 \pm .3$ \\
1350 & $5.8 \pm 0.05$ & $-13.2 \pm 0.4$ \\
1500 & $2.0 \pm 0.03$ & $-12.8 \pm 2.0$ \\
& & \\
Sample \# 18 & & \\
$2.511 \mathrm{~g}$, powder & & \\
$\mathrm{T}\left({ }^{\circ} \mathrm{C}\right)$ & $\mathrm{C}(\mathrm{ppm})$ & \\
500 & $114 \pm 1$ & $-9.5 \pm 0.1$ \\
800 & $431 \pm 4$ & $-4.1 \pm 0.1$ \\
1000 & $42.9 \pm 0.4$ & $-5.6 \pm 0.2$ \\
1200 & $21.7 \pm 0.2$ & $-6.9 \pm 0.3$ \\
1400 & $6.2 \pm 0.1$ & $-16.5 \pm 0.5$ \\
1600 & $0.3 \pm 0.02$ & $-10.8 \pm 10.4$ \\
\hline
\end{tabular}
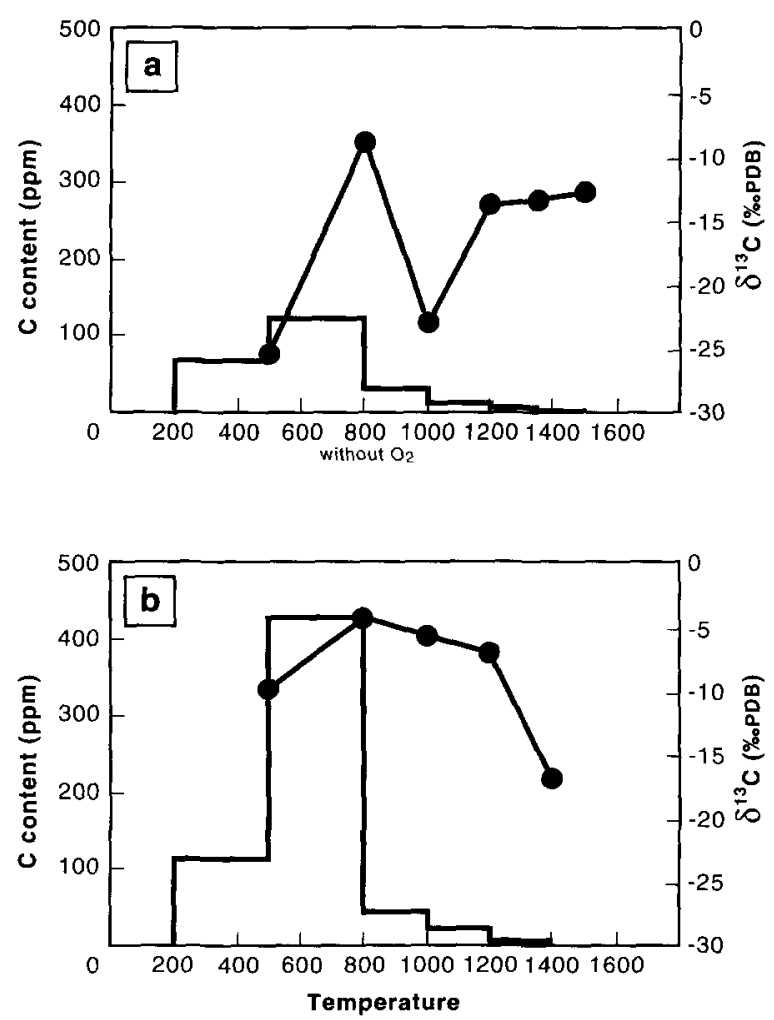

Fig. 2. Carbon step-heating patterns for (a) plagioclase megacryst from the border of the AS massif (sample 10) and (b) ilmenite norite from the Tellnes orebody (sample 18). $\bullet=\delta^{13} \mathrm{C}$ values; histogram $=\mathrm{C}$ contents. composition of carbonates (between 500 and $800^{\circ} \mathrm{C}$, in the absence of $\mathrm{O}_{2}$ ). The remaining carbon is extracted in oxidising conditions: $27 \%$ of bulk carbon $(65 \mathrm{ppm})$ at $T<500^{\circ} \mathrm{C}$ and $21 \%$ (51 ppm) at $T>800^{\circ} \mathrm{C}$ (Fig. 2a). The highest isotopic value $(-8.7 \%$ ) is measured in carbon extracted between 500 and $800^{\circ} \mathrm{C}$. This latter value, approaching the $\delta^{13} \mathrm{C}$ value obtained by acid attack of carbonates $(-5.2 \%)$, also suggests that about half the carbon is in the form of carbonates. As discussed by Wilmart et al. [27], the isotopically light carbon $\left(\delta^{13} \mathrm{C}=-25.9 \%\right)$ released at lower temperatures may correspond to desorbed atmospheric $\mathrm{CO}_{2}$ and 'condensed' carbon, oxidised from complex carbonaceous films. Some submicroscopic graphite particles intimately bound within the plagioclase framework could be released at high temperatures $\left(>1000^{\circ} \mathrm{C}\right.$ ) because it is more difficult to oxidise them. These rare carbon-rich species would have a $\delta^{13} \mathrm{C}$ value close $-13 \%$. The isotopically light carbon extracted between 800 and $1000^{\circ} \mathrm{C}$ is probably due to the tail contributed by the 'condensed' carbon still extracted at these temperatures.

\subsection{The Tellnes orebody}

The $\delta^{18} \mathrm{O}$ values of three ilmenite norites are very restricted $(5.2 \pm 0.2 \% \circ)$, whereas the values are slightly more dispersed $\left(\delta^{18} \mathrm{O}=4.9\right.$ and $6.0 \%$ ) in rocks from a small apophysis of the orebody (sample 20) and in the leuconoritic border facies (sample 21). Carbonate $\delta^{18} \mathrm{O}$ values vary from 12.5 to $17.5 \%$ (Table 1 ).

The Tellnes orebody contains up to $1026 \mathrm{ppm}$ $\mathrm{C}$ with bulk $\delta^{13} \mathrm{C}$ values varying between -6.2 and $-4.1 \%$. These values are quite similar to those measured in carbonates from the orebody $\left(\delta^{13} \mathrm{C}=-3.0 \pm 0.3 \%\right.$ in the ore (ilmenite norite) and $\delta^{13} \mathrm{C}=-4.3$ to $-5.6 \%$ in the leuconoritic border facies and in late quartz calcite veinlets). This suggests that the carbon present in the orebody is essentially in the form of carbonate. The small contribution of possible graphite particles to the carbon content of sample 18 is illustrated in Fig. $2 \mathrm{~b}$ (Table 3): $70 \%$ of the bulk carbon ( 431 $\mathrm{ppm})$ is carbonate with a $\delta^{13} \mathrm{C}$ value of $-4.1 \%$, 
quite similar to the carbon extracted by acid attack ( $437 \mathrm{ppm}$ at $-3.0 \%$ ). If graphite particles are present in the ore, they represent less than $5 \%$ of the bulk carbon ( $28 \mathrm{ppm})$.

\subsection{The Tellnes dyke}

The whole-rock $\delta^{18} \mathrm{O}$ values range from $5.0 \% 0$ in the jotunite (sample\#24) to $6.3 \pm 0.3 \%$ in the charnockites (samples 26 and 27).

Rocks from the Tellnes dyke are relatively rich in carbon compared to anorthosites. They contain 440-1484 ppm bulk carbon with variable $\delta^{13} \mathrm{C}$ $(-7.3$ to $-21.5 \%$ ). An important part of the bulk carbon $(>42 \%)$ is in the form of carbonates with a mean $\delta^{13} \mathrm{C}=-5.7 \pm 0.8 \%$ (if we disregard slightly altered sample 26 ).

\subsection{The BKSK lopolith and the Apophysis}

Samples 28 to 30 represent troctolitic and noritic cumulates from the lower part of the massif and belong to megacyclic unit IV [28], whereas samples 31 to 33 come from the transition zone towards the more acidic rocks of the upper part of the massif, where mangerite (sample 34) is found. Samples 31 and 33 are ultramafic ferrous olivine clinopyroxene Ti-magnetite ilmenite cumulates interleaved with mangeritic cumulates (sample 32) [29]. In the Apophysis, samples 35 and 36 are typical melts in commingling relationships.

The whole-rock $\delta^{18} \mathrm{O}$ values vary between 3.3 and $5.8 \%$ with a mean value of $5.0 \pm 0.9 \%$, significantly lower than values observed in anorthosites.

Whatever their origin (cumulate or liquid), all rocks are richer in carbon than anorthosites, having bulk C contents of 75-1211 ppm (as opposed to less than $50 \mathrm{ppm}$ in anorthosites collected far from the contacts with later intrusions) and $\delta^{13} \mathrm{C}$ values between -19.2 and $-3.8 \%$, depending on the carbon-rich species present. Wilmart and Pineau [30] have shown that carbon is present in charnockites in the form of carbonates $\left(\delta^{13} \mathrm{C}\right.$ values ranging from -6.0 to $-1.8 \%$ ), graphite $\left(\delta^{13} \mathrm{C}\right.$ value of $\left.-17.5 \pm 1.0 \%\right), \mathrm{CO}_{2}$ in fluid inclusions $\left(\delta^{13} \mathrm{C}=-4.4 \pm 2.0 \%\right)$, and in complex carbonaceous molecules (called 'condensed' carbon, with a $\delta^{13} \mathrm{C}$ value $\leqslant-23 \%$ ).

Magmatic rocks from the Tellnes orebody and dyke, from the BKSK lopolith and from the Apophysis usually contain less than $0.30 \% \mathrm{H}_{2} \mathrm{O}$ with $\delta \mathrm{D}$ values ranging from -62.1 to $-90.1 \%$, with the exception of one sample, which represents the border facies of the Tellnes orebody (sample 21) made up of a biotite leuconorite, with $0.53 \%$ and a similar $\delta \mathrm{D}$ value $(-66.9 \%)$.

\subsection{The metamorphic envelope and the anatectic granite}

The carbon contents and $\mathrm{C}$ and $\mathrm{O}$ isotopic compositions of the surrounding metamorphic gneisses are heterogeneous. The gneisses have whole-rock $\delta^{18} \mathrm{O}$ values varying from 2.0 to $9.0 \%$ (Table 1, [31]). Bulk carbon contents range from $\leqslant 20$ to $1077 \mathrm{ppm} \mathrm{C}$ with, the $\delta^{13} \mathrm{C}$ value varying from -4.5 to $-22.4 \%$.

Unlike the other units described, the carbonates represent between 8 and $88 \%$ of the bulk carbon (although generally less than $50 \%$ ). The $\delta^{13} \mathrm{C}$ and $\delta^{18} \mathrm{O}$ values vary from -9.2 to $-3.7 \%$ and from 7.4 to $20.7 \%$, respectively. This suggests a larger contribution of graphite and/or 'condensed' carbon to the bulk carbon, explaining the low bulk $\delta^{13} \mathrm{C}$ value observed.

The two gneisses (39 and 43 ) are slightly richer in water $\left(0.43\right.$ and $0.54 \% \mathrm{H}_{2} \mathrm{O}$, Table 2$)$ than the intrusive rocks. Interestingly, the Breimyrknutan charnockite (sample 46), which resulted from the partial melting of crustal gneisses [32], is very poor in water $(0.17 \%)$, suggesting that the deep crust of Rogaland was almost dry when anatexis occurred. These rocks have the $\delta \mathrm{D}$ values usual for metamorphic rocks (between -69.0 and $-75.4 \%$ ).

\section{Discussion}

\subsection{Oxygen isotopes}

The $\delta^{18} \mathrm{O}$ values measured in the various rocks from the metamorphic envelope vary greatly (by up to $4 \% 0$ ) between gneisses of the same petro- 
graphical type (samples 41 to 43 ) and between gneisses with similar $\mathrm{SiO}_{2}$ contents (samples 38, 39 and 44). The scattered $\delta^{18} \mathrm{O}$ distribution in the surrounding rocks is thus considered to be an original feature.

In contrast, the $\delta^{18} \mathrm{O}$ values measured in anorthosites from the AS massif (Table 1) are very homogeneous, the sixteen anorthosite samples having an average $\delta^{18} \mathrm{O}$ value of $6.1 \pm 0.3 \%$. The range of variation is more restricted in the plagioclase megacrysts $(\sigma=0.1 \%)$ than in anorthositic whole rocks ( $\sigma=0.3 \%$ ), possibly due to the presence of interstitial mafic minerals in the medium-grained anorthosites. These values seem randomly distributed in the massif (Table 1 and Fig. 1). No systematically higher $\delta^{18} \mathrm{O}$ values are observed near the margins, although some $\mathrm{SiO}_{2}$-rich gneisses show $\delta^{18} \mathrm{O}$ values up to $9 \%$. The $\delta^{18} \mathrm{O}$ values of the AS anorthosites fall in the range 5.8-7.6\% defined by Taylor [33] for "normal unmetamorphosed massif-type anorthosites". Our results are consistent with a mantle origin for the Rogaland anorthosites as proposed by Demaiffe and Javoy [31] on the basis of oxygen and strontium isotopic evidence. The narrow range of $\delta^{18} \mathrm{O}$ values observed throughout the AS massif precludes any significant assimilation of country rocks, whose $\delta^{18} \mathrm{O}$ values are quite variable (between 2.0 and $9.0 \%$ ), or of anatectic material such as the Breimyrknutan charnockite $(4.1 \% o)$.

The limited $\delta^{18} \mathrm{O}$ range of the anorthositic rocks may be explained by the small oxygen isotopic fractionation between a basaltic melt and cumulative minerals (titanomagnetite, pyroxene, olivine and plagioclase) at high temperature. Pyroxenes, olivine and Ti-magnetite are slightly depleted in ${ }^{18} \mathrm{O}$, and the plagioclase $\delta^{18} \mathrm{O}$ value is, depending on which study one takes, considered to be similar or slightly higher than the value of the melt $(\Delta<0.5 \%$ at magmatic temperatures [e.g., 34]). Consequently, the $\delta^{18} \mathrm{O}$ value of the parental magma of the anorthosites is expected to be between 5.5 and $6.0 \%$. Calculation of the $\delta^{18} \mathrm{O}$ values of norites and leuconorites from the Tellnes orebody based on their mineralogy and modal composition, together with the mineral oxygen fractionation factors, perfectly fits the measured $\delta^{18} \mathrm{O}$ whole-rock values if we assume a parental magma at $5.5 \%$. This assumed initial $\delta^{18} \mathrm{O}$ value is also similar to the isotopic composition of the parental magma of anorthosites and will support a comagmatic origin for the AS anorthosite and the orebody as previously proposed by Wilmart et al. [23].

Similarly, oxygen isotopic variations observed within the Tellnes dyke can be explained by fractional crystallisation from a jotunitic melt giving rise to mangeritic and finally to charnockitic melts [26].

In addition, the variations in the $\delta^{18} \mathrm{O}$ values obtained in the various cumulate rocks from the BKSK lopolith essentially reflect the modal proportion of feldspars, Fe-Ti oxides, olivine and pyroxenes. For example, the lowest $\delta^{18} \mathrm{O}$ values were measured in mafic cumulates (samples 31 and 33) while the highest one was obtained in the mesoperthite-bearing cumulate rocks (e.g., sample 32).

\subsection{Carbon concentration and $\delta^{13} C$ values}

The low carbon contents $(<50 \mathrm{ppm} \mathrm{C})$ of the anorthosites collected more than $500 \mathrm{~m}$ from the massif borders could indicate either that the anorthositic crystal mush was $\mathrm{C}$-poor when emplaced in the metamorphic envelope or that it lost most of its original $\mathrm{C}$ during or after cooling. However, the heterogeneity in carbon and oxygen contents and in the isotopic compositions in the various gneisses of the envelope, together with the absence of metamorphic overprinting in the Rogaland Igneous Province, does not favour the latter hypothesis. Indeed, the cumulate nature of the anorthosites is a strong argument for an originally low carbon content, most of the carbon having been concentrated in the residual melt or degassed from the magma into the overlying crust (Fig. 5).

Fig. 1 shows the distribution of the bulk carbon content in all the anorthosite samples and in the neighbouring units. A significant increase in carbon content (up to $790 \mathrm{ppm}$ ) is observed in all anorthosites and plagioclase megacrysts occurring in the vicinity of the neighbouring igneous and metamorphic rocks. This increase in carbon con- 
tent corresponds to the appearance of interstitial carbonates. Both observations suggest that the carbon-poor anorthosites have been infiltrated by carbon-rich fluids, either exsolved from later intruded magmas or coming from the metamorphic envelope. The results of step-heating experiments performed on a relatively C-rich plagioclase megacryst (sample 10, see section 4.1) indicate that the carbon extracted from the crystals is mainly in the form of carbonate, with a small proportion of reduced carbon released at low temperature. Such reduced carbon may correspond to complex carbonaceous molecules condensed along cracks and grain boundaries at decreasing temperature and oxygen fugacity $[35,36]$ and to some graphite microcrysts. Previous studies $[37,38]$ have shown that the carbon isotopic fractionation which takes place during the formation of such complex molecules (by Fischer Tropsch reactions) is large; this prohibits the use of such phases to characterise the carbon isotopic signature of the C-rich fluid.

The limited extent (a few hundreds metres) of infiltration from neighbouring rocks into the anorthosite may imply that the amount of fluid was small and that infiltration occurs mainly in a closed system. By assuming closed system conditions, we can approach the isotopic composition of the infiltrating fluid by integrating all the carbonic phases observed in the infiltrated samples (average of $285 \mathrm{ppm} \mathrm{C}$ with a weighted mean value of $-6.8 \%$ ) and subtracting from this the mean carbon content of unaffected anorthosites (30 ppm at ca. $-20.0 \%$ ) estimated from uncontaminated samples. The estimated $\delta^{13} \mathrm{C}$ value of the infiltrating fluid is close to $-5.3 \%$. Another interpretation would be that huge amounts of carbon passed through the rocks but left no trace, due either to (i) there being no phase available in which carbon could be fixed at high temperatures or (ii) to there being no hydrous phases that could break down to record the passage of carbon dioxide by dehydration halos. In this second interpretation, the carbon measured in anorthosites would record residual $\mathrm{CO}_{2}$ left after the fluid flow has ceased. Assuming that carbonate precipitation occurred in isotopic equilibrium with $\mathrm{CO}_{2}$ at a temperature around $700^{\circ} \mathrm{C}$ and using Bot- tinga [39] fractionation factors, the fluid $\delta^{13} \mathrm{C}$ value would be around $-2.5 \%$, which is quite different from our estimate. Moreover, the reason why some residual fluid would be trapped only in anorthosites located at the borders of the massif is not accounted for in the second model. On the other hand, the carbon isotopic composition calculated for the fluid phase in the first model is typical of an upper mantle $\mathrm{C}$ source such as estimated from $\mathrm{CO}_{2}$-rich vesicle basalts $(-7$ to $-3.6 \%$ in popping rocks [40]), and from diamonds ( -7 to $-2 \%$ [41]).

Late carbonates have been observed throughout the Marcy Anorthosite Massif (Adirondack Mountains, New York) and have been related to late hydrothermal fluids that have altered the anorthosite massif after the igneous events and the granulite facies metamorphism [42]. In the AS massif however, no metamorphism occurred after the igneous events, and the fact that carbonate distribution appears limited to a few hundred metres from the margin of the massif suggests that the carbonate precipitation was related to the intrusion of neighbouring units.

The Tellnes orebody is suggested to have been a major source of $\mathrm{C}$-rich fluids which allowed carbonate precipitation in the anorthosite. Ironrich magmas are known to dissolve large amounts of carbon [43]. This is also confirmed by the high bulk $\mathrm{C}$ contents measured in the Tellnes orebody (395-1026 ppm) and in the anorthosites collected in its vicinity (up to $790 \mathrm{ppm}$ ). The Tellnes dyke also appears to affect the anorthosite (e.g., sample 14 taken at the contact with the dyke yields a bulk C content of $161 \mathrm{ppm}$ ).

The BKSK lopolith contains variable amounts of carbon, and the carbonate shows high $\delta^{13} \mathrm{C}$ values. The western contact of the AS massif with the BKSK lopolith has been little studied. Sample 9 collected $1 \mathrm{~km}$ from the contact shows no carbon enrichment and thus could indicate the limit of fluid infiltration. One anorthosite sample (4) collected $2.7 \mathrm{~km}$ from the contact with the BKSK lopolith contains relatively high amounts of carbon (113 ppm C). Since such $\mathrm{C}$ contents and the carbonate $\delta^{13} \mathrm{C}$ values $(-7.4 \%)$ are quite similar to those measured in samples which have been influenced by the neighbouring intru- 
sions, the simplest explanation could be the presence of a hidden dyke or pod a few metres from the actual level of exposure or the existence of a fluid flow channel.

As already mentioned, the eastern limit of the AS massif, which corresponds to the contact with the Apophysis, also shows an increase in the carbonate content (Fig. 1 and Table 1). Because the Apophysis intruded between the anorthosite massif and its metamorphic envelope, the source of the fluid fluxing into the anorthosite massif is somewhat ambiguous-it may come from the Apophysis and/or from the crustal metamorphic envelope.

While carbon in contaminated anorthosites is mainly in the form of carbonate, reduced carbonaceous species are usually predominant in rocks from the crustal metamorphic envelope, suggesting that the gneisses have preserved some 'original' carbon characteristics. The differences between the $\delta^{13} \mathrm{C}$ values of the carbonates and those of the calculated 'graphite' of samples 38 , $40,42,43$ and 45 vary widely, from 20.1 to $6.5 \%$. Such large differences, which are associated with carbonate $\delta^{18} \mathrm{O}$ values typical of intermediate temperature precipitation (see below), show that there is no isotopic equilibrium between the carbonates and graphite. The lack of equilibrium may accord with the idea that some of the carbonate was added by the neighbouring intrusions. Indeed, the granitic gneisses (e.g., sample 45), which constitute a major rock type in the metamorphic envelope and which were collected far from the contact with the Apophysis, are very poor in carbonate. It is thus suggested that (i) the carbon influx evident in the border anorthosites is associated with the intrusion of the Apophysis and (ii) that the later intrusion had also enriched the metamorphic envelope in carbon.

The relationship between the bulk carbon content and the associated $\delta^{13} \mathrm{C}$ values is shown in Fig. 3. A carbonate field is delimited by the carbonate-rich samples. The contaminated AS anorthosites plot along the calculated mixing curves between an uncontaminated end member (estimates at $43 \mathrm{ppm} \mathrm{C}$ and $-20.4 \%$ ) and various amounts of carbonates (100 and $1000 \mathrm{ppm} \mathrm{C}$ at $-4 \% 0$ ) precipitated from a magmatic carbonrich fluid. A similar interpretation can be applied to samples from the metamorphic envelope which

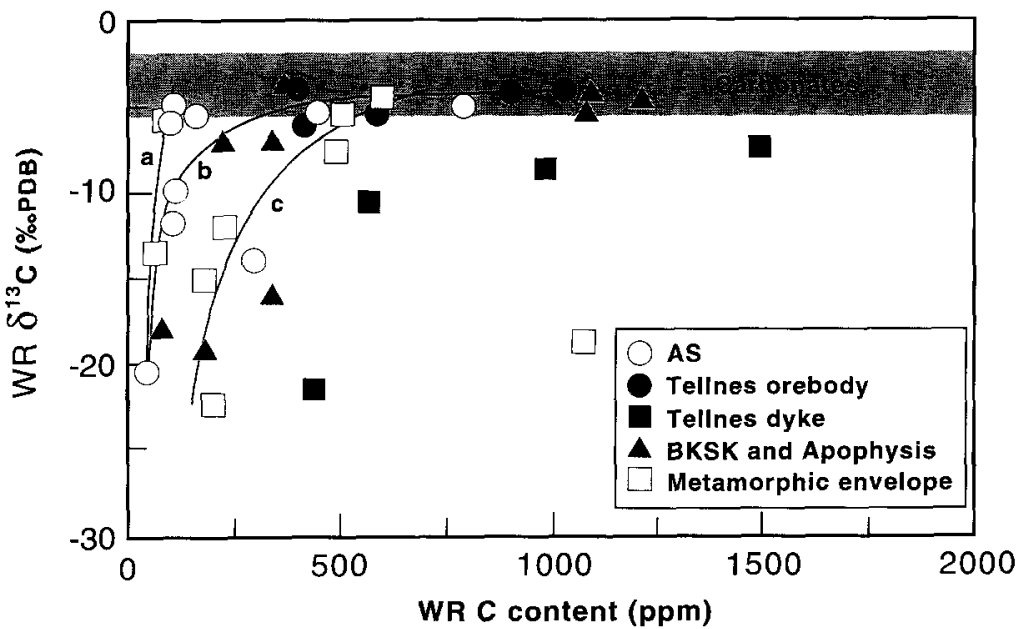

Fig. 3. Bulk carbon contents and isotopic compositions in rocks from Rogaland. The carbon contents and isotopic compositions of the anorthosites and metamorphic rocks fall along mixing lines between two different carbon species, a light isotopic carbon component ( $43 \mathrm{ppm} \mathrm{C} \mathrm{at}-20.4 \%$ for anorthosites and $150 \mathrm{ppm} \mathrm{C}$ at $-22.4 \%$ for metamorphic rocks) and carbonates (10-1000 $\mathrm{ppm} C$ for anorthosites (curves $a$ and $b$ ) and $700 \mathrm{ppm} \mathrm{C}$ for metamorphic rocks (curve $c$ ) at $-4.0 \%$ ). The carbonates were precipitated from a magmatic fluid associated with late intrusions (Tellnes orebody, BKSK and the Apophysis, and Tellnes dyke). Carbon in the late intrusions is clearly concentrated in the carbonates. 
plot along a curve starting with a higher initial carbon content (estimated at $150 \mathrm{ppm}$ of isotopically light graphite $(-23 \%)$ mixed with carbonates derived from the intruding magmas).

The bulk carbon contents of the later intrusions (Tellnes orebody and dyke, BKSK, and the Apophysis) generally show isotopic signatures close to the magmatic carbonate end member defined above. The five samples poorest in $\mathrm{C}$ (three cumulates from the BKSK lopolith $(31,33$ and 34) and the two samples of the Tellnes dyke richer in $\mathrm{SiO}_{2}$ (26 and 27)) show significantly lower $\delta^{13} \mathrm{C}$ values. The carbon distribution in the Tellnes dyke is similar to the major and trace element variation in the rocks which were explained by a fractional crystallisation process.

The proportions of the carbonaceous phases formed at the expense of the fluid phase (carbonate and condensed carbon) vary from place to place. The trends observed in Fig. 3 may be also due to the mixing of these two carbon-rich species. However, it must be kept in mind that isotopic fractionation may also affect the fluid phase during carbonate precipitation.

\subsection{Carbonate isotopic signature}

The carbonate $\delta^{18} \mathrm{O}$ values range from 8.9 to $15.6 \%$ in the AS massif, from 7.8 to $19.5 \%$ in the other magmatic units and from 7.4 to $20.7 \%$ in the metamorphic envelope. The unaltered character of the rocks is demonstrated by the restricted range of whole-rock $\delta^{18} \mathrm{O}$ values (Table 1 ), although it is possible that some late isotopic exchange between carbonates and traces of water occurred at the grain boundaries. This water is considered to be either water exsolved from the magmas, concomitantly with $\mathrm{CO}_{2}$, or meteoric water. Calibrations obtained on the feldspar water system $[44,45]$, on the $\mathrm{H}_{2} \mathrm{O}$ calcite system [39] and on the calcite anorthite water-free system [46] provide limits for oxygen isotopic equilibrium between calcite and anorthite. In the AS massif, carbonates with $\delta^{18} \mathrm{O}$ values lower than $10 \%$ crystallised or re-equilibrated at temperatures higher than $500^{\circ} \mathrm{C}$ and no anorthosite samples suffered re-equilibration below $250^{\circ} \mathrm{C}$. Such limits seem to be valid for most carbonates present in other units, meteoric alteration having to be invoked to explain the higher $\delta^{18} \mathrm{O}$ values $(>16 \%$ ) measured in only $20 \%$ of the rocks studied.

All the carbonate $\delta^{13} \mathrm{C}$ values fall in the range accepted for fluid and carbonate associated with mantle-derived magmas ( -4 to $-8 \%$, [e.g., 47,48]). However, the data reported in Table 1 show that carbonates from the carbon-rich intrusions (the BKSK lopolith, the Apophysis and the Tellnes orebody) are often richer in ${ }^{13} \mathrm{C}\left(\delta^{13} \mathrm{C}=\right.$ $-3.5 \pm 1.0 \%$ ) than the carbonates introduced into the AS massif and the metamorphic envelope by the previous intrusions (carbonate $\delta^{13} \mathrm{C}$ $=-7$ to $-4 \%$; average $-5.8 \pm 1.8 \%$ ). For example, anorthositic sample 16, collected less than $1 \mathrm{~km}$ from the Apophysis jotunite and mangerite (samples 35 and 36), has a carbonate $\delta^{13} \mathrm{C}$ value of $-6.2 \%$, against -3.4 and $-1.8 \%$ in the Apophysis samples. The higher $\delta^{13} \mathrm{C}$ values may be explained by the formation of carbonaceous molecules ('condensed' carbon) in equilibrium with the fluid from which the carbonates precipitate. On the other hand, the lowering of carbonate $\delta^{13} \mathrm{C}$ values can result from diffusion effects and/or from isotopic fractionation during carbonate precipitation at decreasing temperatures. A carbon isotopic fractionation of $7.8 \%$ measured between carbonates $\left(\delta^{13} \mathrm{C}=-5.2 \%\right)$ and graphite $(-13.0 \%$, see section 4.1$)$ in the contaminated anorthosite (sample 10) indicates that these two carbonic phases re-equilibrated down to $450^{\circ} \mathrm{C}$ [49].

An equilibration temperature of $95^{\circ} \mathrm{C}$ was calculated from the $\delta^{18} \mathrm{O}$ values of calcite and quartz in a late calcite-quartz veinlet cross-cutting the Tellnes orebody and the anorthosite. This indicates that a carbon-rich fluid continued to percolate along fractures after solidification of the rocks.

\subsection{Hydrogen concentration and $\delta D$ values}

The low water content $(0.12-0.54 \%$, Table 2) found within all the units confirms the good preservation of the granulite facies conditions during cooling and uplift. In most samples the $\delta \mathrm{D}$ values $(-81.8$ to $-62.6 \%)$ are in the field defined for magmatic rocks [47]. The relation- 
ships between $\mathrm{H}_{2} \mathrm{O}$ contents, $\delta \mathrm{D}$ and whole-rock $\delta^{18} \mathrm{O}$ values are shown in Fig. 4. A weak negative correlation between $\delta \mathrm{D}$ and water content, possibly resulting from the magmatic evolution of the system [50], is observed in Fig. 4a. Sample 8 (Table 1) was collected from a fracture zone in order to characterise the alteration processes due to the circulation of meteoric water. An increase in water content $(0.69 \%)$ and $\delta \mathrm{D}$ value $(-53.6 \% 0)$ is observed but the small change in the $\delta^{18} \mathrm{O}$ value $(6.4 \%$, Fig. $4 \mathrm{~b})$ implies that the fluid-rock interaction occurred at relatively high temperatures with hydrothermal fluids buffered completely by anorthosite (low water/rock ratio).
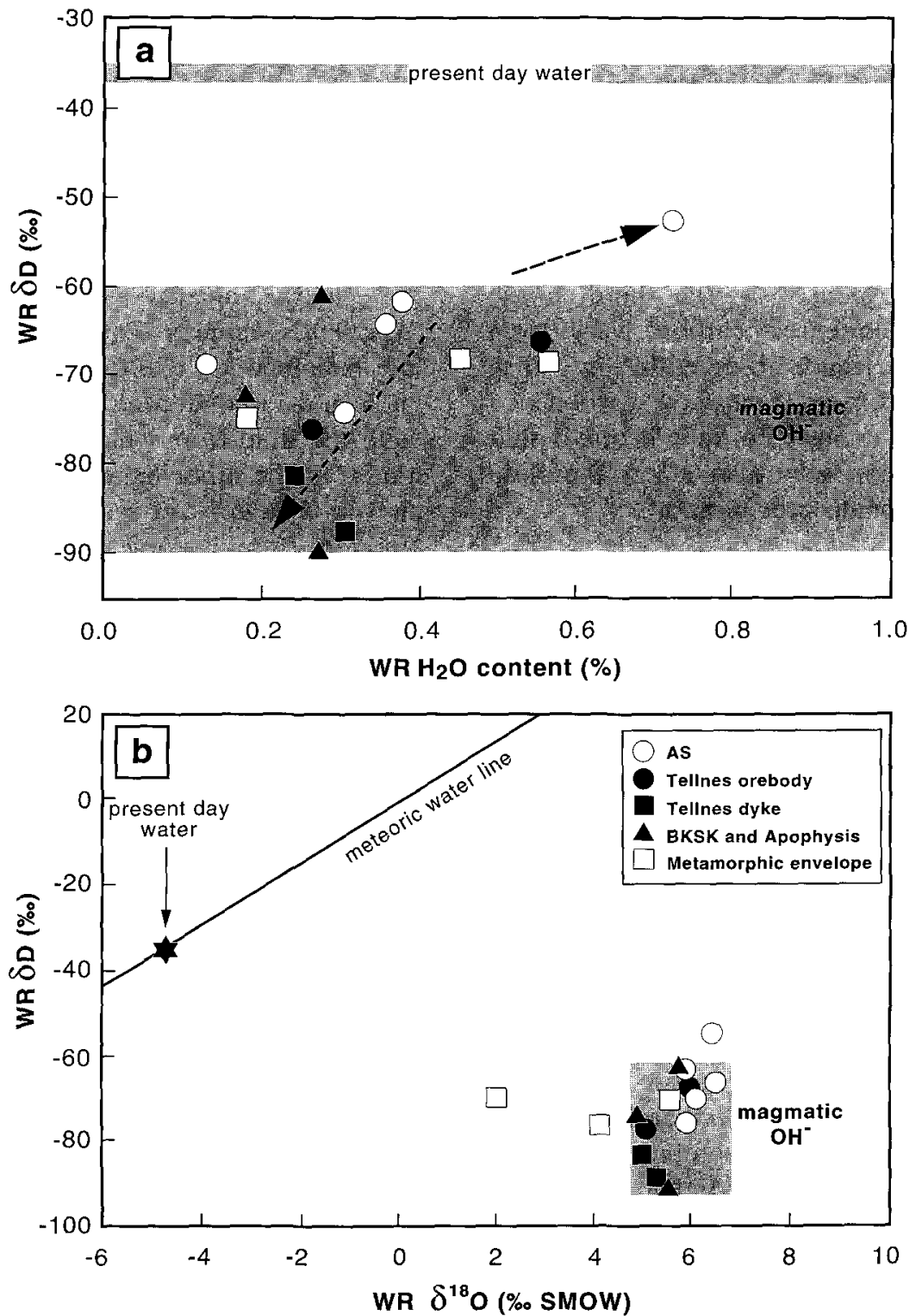

Fig. 4. (a) Whole-rock (WR) $\delta \mathrm{D}$ vs. $\mathrm{H}_{2} \mathrm{O}$ and (b) whole-rock $\delta \mathrm{D}$ vs. $\delta^{18} \mathrm{O}$ for all rock units. Also shown are the fields for magmatic hydroxyl and present-day water. 
Because of the relatively restricted range of $\delta \mathrm{D}$ values and the good preservation of the whole-rock $\delta^{18} \mathrm{O}$ values, we propose that the water corresponds mainly to magmatic 'water' fixed as hydroxyl radicals in silicates under the $P-T$ conditions of crystallisation, as has been demonstrated for diopside [51].

\subsection{Implications for $\mathrm{CO}_{2}$ transfer}

The role of mantle-derived magmas as a source of heat and $\mathrm{CO}_{2}$ inducing the granulitization of the lower continental crust has been discussed by several authors [e.g., 5,52]. In estimating the importance of $\mathrm{CO}_{2}$ associated with the anorthositic magmatism in Rogaland, we propose the following:

An anorthosite parental magma, just saturated in carbonate ions, was stored at the base of a thickened crust (12 or $15 \mathrm{kbar}$, estimated on the basis of the Al content of orthopyroxene megacrysts [53]). The amount of volatiles dissolved in the magma before any crystallisation would have been about 3000 ppm C [54] (Fig. 5) for a tholeiitic composition. (Note that although the volatile content may have been higher if the magma was richer in alkalis [55] or iron [43], this has little effect on the proposed scenario.) During crystallisation in the magma chamber, the volatiles were concentrated in the residual liquid and the fluid reached a supersaturation factor of 2 , which is sufficient for the nucleation of $\mathrm{CO}_{2}$ bubbles [56]. The $\mathrm{CO}_{2}$ bubbles were partially incorporated in anatectic melts derived from the melting of the lower crust (charnockitic and/or jotunitic [57]) that were emplaced soon after the emplacement of the anorthosite diapirs (the BKSK lopolith, the Apophysis and the Tellnes dyke). Because these magmas were of intermediate composition (and thus had a lower carbon saturation level than the anorthosite parental magma) and represent less than 30 vol\% of the anorthosite massif, they would have been saturated in $\mathrm{CO}_{2}$ comprising a free fluid phase. Consequently, these later intrusions released $\mathrm{CO}_{2}$ into the surrounding rocks (anorthosites and gneisses). The extent of infiltration of $\mathrm{CO}_{2}$-rich fluids (into the AS anorthosite and the metamorphic envelope) was

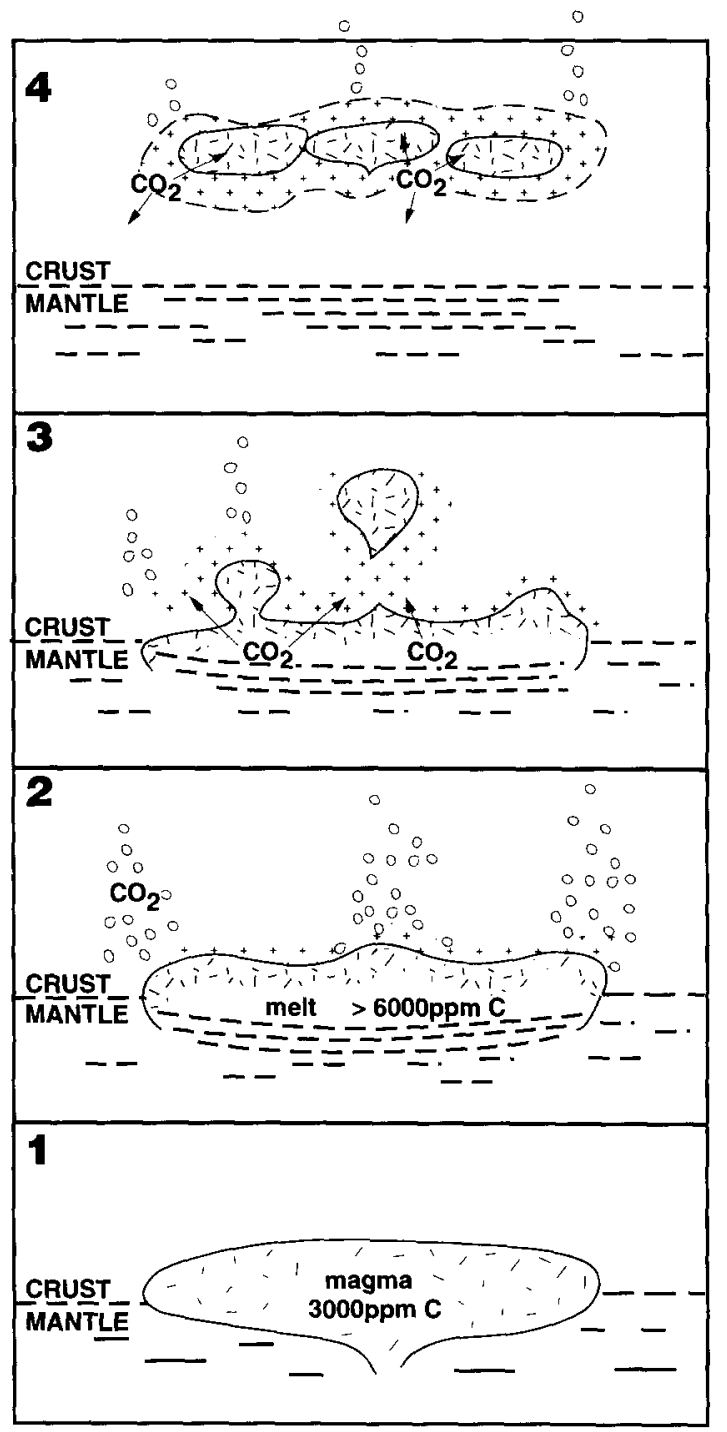

Fig. 5. Scenario of the anorthosite formation and emplacement [after 9,11,18,58] and implications for $\mathrm{CO}_{2}$ transfer. (1) A basaltic magma containing $3000 \mathrm{ppm} \mathrm{C}$ ponds at the base of the crust. (2) Extensive crystallisation produces ultramafic cumulates and a floating suspension of plagioclase. The residual liquid, supersaturated in $\mathrm{CO}_{2}$, releases $\mathrm{CO}_{2}$ bubbles which stream into the lower crust. The lower crust starts anatectic melting. (3) Due to gravitational instabilities in the plagioclase mush, several diapirs of anorthosite detach from the roof of the magma chamber. Crustal melts rise together with the diapirs and incorporate part of the $\mathrm{CO}_{2}$. (4) The intrusions stop at their final level of emplacement. Some of the $\mathrm{CO}_{2}$ produced by the crystallisation of the crustal melts is reintroduced into the anorthosites and the metamorphic envelope. The ultramafic cumulates become indistinguishable from the rest of the mantle. 
previously observed to be restricted, and thus we propose that carbon-rich fluids were introduced at higher levels in the crust along channels.

\section{Conclusions}

(1) The AS anorthositic massif has a restricted range of $\delta^{18} \mathrm{O}$ values of $6.1 \pm 0.3 \%$. The anorthosites (and the supposedly comagmatic Tellnes orebody) may have formed by the crystal fractionation of a mantle-derived magma with an initial $\delta^{18} \mathrm{O}$ value of $5.5 \%$.

(2) The low water content of the anorthosites and surrounding rocks $\left(<0.54 \% \mathrm{H}_{2} \mathrm{O}\right)$ confirms the good preservation of the granulite facies conditions (hydrous minerals are rare). Some of the water present in the intrusive rocks may represent hydroxyl radicals within the framework of the silicate minerals.

(3) The cumulative origin of the anorthosites explains the low carbon content $(<50 \mathrm{ppm} \mathrm{C})$ that is observed in the samples collected far from the contacts with the other magmatic units.

(4) It is suggested that fluids are an important component of magmatic activity in the lower crust. They are released by the fractional crystallisation of magmas derived within the mantle or deep within the continental crust.

(5) The fluid phase produced migrated along grain boundaries and into the surrounding rocks, precipitating interstitial carbonate and (probably in a later stage) some more complex carbonaceous molecules, although the isotopic signature of the carbon-rich fluid is better reflected by the carbonate phase.

(6) In the granulitic Rogaland Igneous Province carbonic fluids were produced during the latestage emplacement of intrusions into the anorthosite massif, a cumulate, poor in carbon, which was emplaced as a crystal mush. The distribution of $\mathrm{C}$ suggests strongly that the influx of $\mathrm{CO}_{2}$ from the later intrusions was restricted to a distance of about $500 \mathrm{~m}$ within the anorthositic massif. The rocks of the metamorphic envelope in the vicinity of the intrusions underwent a similar $\mathrm{CO}_{2}$ enrichment.
(7) It is suggested that fluid movements in the lower crust are not pervasive but controlled mainly by fractures.

(8) This work does not contradict the hypothesis that the granulite facies of Rogaland is the consequence of contact metamorphism around the intrusives, but rather questions the role of $\mathrm{CO}_{2}$ streaming as a controlling factor.

\section{Acknowledgements}

This work was supported by a CNRS grant (DBT 4, Fluides, minéraux et cinétique, 1991) and contributes to IGCP Project 290. We thank M. Javoy, P. Agrinier, S. Boyd and S. Nadeau for their helpful comments and R.C. Newton and B.R. Frost for their constructive and helpful reviews. This work is IPGP contribution 1309 and CNRS-INSU contribution 678.

\section{References}

[1] A.S. Janardhan, R.C. Newton and E.C. Hansen, The transformation of amphibolite facies gneiss to charnockite in southern Karnataka and northern Tamil Nadu, India, Contrib. Mineral. Petrol. 79, 130-149, 1982.

[2] R.C. Newton, J.V. Smith and B. Windley, Carbonic metamorphism, granulites and crustal growth, Nature $288,45-50,1980$.

[3] R.C. Newton, Fluids of granulite facies metamorphism, in: Fluid-Rock Interactions During Metamorphism (Advances in Physical Geochemistry 5), J.V. Walther and B.J. Wood, eds., pp. 36-59, Springer, New York, 1986.

[4] W. Lamb and J.W. Valley, Metamorphism of reduced granulites in low- $\mathrm{CO}_{2}$ vapour-free environment, Nature 312, 56-58, 1984.

[5] B.R. Frost and C.D. Frost, $\mathrm{CO}_{2}$ melts and granulite metamorphism, Nature 327, 503-506, 1987.

[6] U.B. Andersson, L. Larsson and A. Wikström, Charnockites, pyroxene granulites, and garnet-cordierite gneisses at a boundary between early Svecofennian rocks and Småland-Värmland granitoids, Karlskoga, southern Sweden, Geol. Foeren. Stockholm. Foerh. 114, 1-15, 1992.

[7] J.A. Percival, Granulite-facies metamorphism and crustal magmatism in the Ashuanipi Complex, Quebec-Labrador, Canada, J. Petrol. 32, 1261-1297, 1991.

[8] M. Santosh and M. Yoshida, A petrologic and fluid inclusion study of charnockites from the Lützow-Holm Bay region, East Antarctica: Evidence for fluid-rich metamorphism in the lower crust, Lithos 29, 107-126, 1992. 
[9] R.F. Emslie, Proterozoic anorthosite massifs, in: The Deep Proterozoic Crust in the North Atlantic Provinces (NATO ASI Ser. C158), A.C. Tobi and J.L.R. Touret, eds., pp. 39-60, Reidel, Dordrecht, 1985.

[10] R.A. Wiebe, Proterozoic anorthosite complexes, in: Proterozoic Crustal Evolution, K.C. Condie, ed., pp. 215-261, Elsevier, Amsterdam, 1993.

[11] J.C. Duchesne, Massif anorthosites: another partisan review, in: Feldspars, Feldspathoids and their Paragenesis (NATO ASI Ser. C137), W.S. Brown, ed., pp. 411-437, Reidel, Dordrecht, 1984.

[12] A.C. Tobi, G.A.E.M. Hermans, C. Maijer and J.B.H. Jansen, Metamorphic zoning in the high-grade Proterozoic of Rogaland-Vest Agder, SW Norway, in: The Deep Proterozoic Crust in the North Atlantic Provinces (NATO ASI Ser. C158), A.C. Tobi and J.L.R. Touret, eds., pp. 477-498, Reidel, Dordrecht, 1985.

[13] J. Van der Auwera, Diffusion controlled growth of pyroxene-bearing margins on amphibolite bands in the granulite facies of Rogaland (Southwestern Norway): implication for granulite formation, Contrib. Mineral. Petrol. 114, 203-220, 1993.

[14] M. Javoy, F. Pineau and H. Delorme, Carbon and nitrogen isotopes in the mantle, Chem. Geol. 57, 41-62, 1986.

[15] T.M. Gerlach and B.E. Taylor, Carbon isotope constraints on degassing of carbon dioxide from Kilauea volcano, Geochim. Cosmochim. Acta 54, 2051-2058, 1990.

[16] H. Krause and G. Pedall, Fe-Ti mineralizations in the Ana-Sira anorthosite, Southern Norway, Finl. Geol. Surv. Bull. 307, 56-83, 1980.

[17] P. Michot, La géologie de la catazone: le problème des anorthosites, la palingenèse basique et la tectonique catazonale dans le Rogaland méridional (Norvège méridionale), Nor. Geol. Unders. 212, 1-54, 1960.

[18] R. Maquil and J.C. Duchesne, Géothermométrie par les pyroxènes et mise en place du massif anorthositique d'Egersund-Ogna (Rogaland, Norvège méridionale), Ann. Soc. Géol. Belg. 107, 27-49, 1984.

[19] E. Wilmart and J.C. Duchesne, Geothermobarometry of igneous and metamorphic rocks around the Ana-Sira anorthosite massif: implication for the depth of emplacement of the South Norwegian anorthosites, Nor. Geol, Tidsskr. 67, 185-196, 1987.

[20] D. Demaiffe, D. Weis, J. Michot and J.C. Duchesne, Isotopic constraints on the genesis of the Rogaland anorthositic suite, Chem. Geol. 57, 167-179, 1986.

[21] E. Wilmart, Série supracrustale, granito-gneiss et charnockites de l'enveloppe métamorphique du massif anorthositique d'Åna-Sira (Rogaland, Norvège méridionale): étude pétrographique et géochimique, Mém. Lic. Thesis, Univ. Liège, 1982 (Unpubl.).

[22] J.C. Duchesne, The Bjerkreim-Sokndal massif, in: The Geology of Southernmost Norway: An Excursion Guide, C. Maijer and P. Padget, eds., Nor. Geol. Unders. Spec. Publ. 1, 56-59, 1987.

[23] E. Wilmart, D. Demaiffe and J.C. Duchesne, Geochemical constraints on the genesis of the Tellnes ilmenite deposit, southwestern Norway, Econ. Geol. 84, 10471056, 1989.

[24] J.C. Duchesne, U. Schärer and E. Wilmart, A $10 \mathrm{Ma}$ period of emplacement for the Rogaland anorthosites, Norway: evidence for U-Pb ages, Terra Abstr. Suppl. 1, Terra Nova 5, 64, 1993.

[25] J. Rosenbaum and S.M.F. Sheppard, An isotopic study of siderites, dolomites and ankerites at high temperatures, Geochim. Cosmochim. Acta 50, 1147-1150, 1986.

[26] R.N. Clayton and T.K. Mayeda, The use of bromine pentafluoride in the extraction of oxygen from oxides and silicates for isotopic analysis, Geochim. Cosmochim. Acta 27, 43-52, 1963.

[27] E. Wilmart, M. Mosbah and F. Pineau, Carbon in igneous minerals of granulites from Rogaland (Norway): nuclear microanalysis and isotope geochemistry, Eur. J. Mineral., in press.

[28] J.C. Jensen, F.M. Nielsen, J.C. Duchesne, D. Demaiffe and J.R. Wilson, Magma influx and mixing in the Bjerkreim-Sokndal layered intrusion, South Norway: evidence from the boundary between two megacyclic units at Storeknuten, Lithos 29, 311-325, 1993.

[29] J.C. Duchesne, B. Denoiseux and J. Hertogen, The norite-mangerite relationships in the Bjerkreim-Sokndal layered lopolith (Southwest Norway), Lithos 20, 1-17, 1987.

[30] E. Wilmart and F. Pineau, Role of mantle fluids in the lower crust: evidence from anorthosites and granulites from Rogaland (SW Norway), IGCP 290, Anorthosite Conf. (Moi, Norway), June 1-6, 1992 (Abstr.).

[31] D. Demaiffe and M. Javoy, ${ }^{18} \mathrm{O} /{ }^{16} \mathrm{O}$ ratios of anorthosites and related rocks from Rogaland Complex (SW Norway), Contrib. Mineral. Petrol. 72, 311-317, 1980.

[32] J.C. Duchesne, D. Demaiffe and E. Wilmart, FidselVardefjell-Itland: Apophysis, Hidra massif and envelope, in: The Geology of Southernmost Norway: An Excursion Guide, C. Maijer and P. Padget, eds., Nor. Geol. Unders. Spec. Publ. 1, 42-47, 1987.

[33] H.P. Taylor, Oxygen isotope studies of anorthosites, with particular reference to the origin of bodies, in: Origin of Anorthosites and Related Rocks, Y.W. Isachsen, ed, N.Y. State Mus. Sci. Serv. Mem. 18, 111-134, 1969.

[34] R.I. Kalamarides, Kiglapait geochemistry VI: Oxygen isotopes, Geochim. Cosmochim. Acta 48, 1827-1836, 1984.

[35] E.A. Mathez and J.R. Delaney, The nature and distribution of carbon in submarine basalts and peridotite nodules, Earth Planet. Sci. Lett. 56, 217-232, 1981.

[36] E.A. Mathez, Carbonaceous matter in mantle xenoliths: composition and relevance to the isotopes, Geochim. Cosmochim. Acta 51, 2339-2347, 1987.

[37] S. Nadeau, F. Pineau, M. Javoy and D. Francis, Carbon concentrations and isotopic ratios in fluid-inclusionbearing upper mantle xenoliths along the northwestern margin of North America, Chem. Geol. 81, 271-297, 1990.

[38] F. Pineau and E.A. Mathez, Carbon isotopes in xenoliths from the Hualalai volcano, Hawaii, and the generation of 
isotopic variability, Geochim. Cosmochim. Acta 54, 217$227,1990$.

[39] Y. Bottinga, Calculations of fractionation factors for carbon and oxygen exchange in the system calcite-carbon dioxide-water, J. Phys. Chem. 72, 800-808, 1968.

[40] M. Javoy and F. Pineau, The volatiles record of a 'popping' rock from the Mid-Atlantic Ridge at $14^{\circ} \mathrm{N}$ : Chemical and isotopic composition of gas trapped in the vesicles, Earth Planet. Sci. Lett. 107, 598-611, 1991.

[41] S.R. Boyd, F. Pineau and M. Javoy, Modelling the growth of natural diamonds, Chem. Geol., in press.

[42] J. Morrison and W. Valley, Post-granulite facies fluid infiltration in the Adirondack Mountains, Geology 16, 513-516, 1988.

[43] J.R. Weidner, Iron-oxide magmas in the system Fe-C-O, Can. Mineral. 20, 555-566, 1982.

[44] J.R. O'Neil and H.P. Taylor, The oxygen isotope and cation exchange chemistry of feldspars, Am. Mineral. 52, 1414-1437, 1967.

[45] Y. Matsuhisa, J.R. Goldsmith and R.N. Clayton, Oxygen isotope fractionation in the system quartz-albiteanorthite-water, Geochim. Cosmochim. Acta 43, 11311140, 1979.

[46] R.N. Clayton, J.R. Goldsmith and T.K. Mayeda, Oxygen isotope fractionation in quartz, albite, anorthite, and calcite, Geochim. Cosmochim. Acta 53, 725-733, 1989.

[47] B.E. Taylor, Magmatic volatiles: isotopic variation of C, $\mathrm{H}$, and $\mathrm{S}$, in: Stable Isotopes in High Temperature Geological Processes, J.H. Valley, H.P. Taylor, Jr. and J.R. O'Neil, eds., Rev. Mineral. 16, 185-226, 1986.

[48] M. Javoy, F. Pineau and H. Delorme, Carbon and nitrogen isotopes in the mantle, Chem. Geol. 57, 41-62, 1986.

[49] Y. Bottinga, Carbon isotope fractionation between graphite, diamond and carbon dioxide, Earth Planet. Sci. Lett. 5, 301-307, 1969.

[50] J.R. O' Neil and B.W. Chappell, Oxygen and hydrogen isotope relations in the Berridale batholith, J. Geol. Soc. London 133, 559-571, 1977.

[51] J. Ingrin, K. Latrous, J.C. Doukhan and N. Doukhan, Water in diopside: an electron microscopy and infrared spectroscopy study, Eur. J. Mineral. 1, 327-341, 1989.

[52] F. Pineau, M. Javoy, F. Behar and J. Touret, La géochimie isotopique du faciès granulite du Bamble (Norvège) et l'origine des fluides carbonés dans la croûte profonde, Bull. Minéral. 104, 630-641, 1981.

[53] M.S. Fram and J. Longhi, Phase equilibria of dikes associated with Proterozoic anorthosite complexes, Am. Mineral. 77, 605-616, 1992.

[54] V. Pan, J.R. Holloway and R.L. Hervig, The pressure and temperature dependence of carbon dioxide solubility in tholeiitic basalt melts, Geochim. Cosmochim. Acta 55, 1587-1595, 1991.

[55] B.O. Mysen, The solubility of $\mathrm{H}_{2} \mathrm{O}$ and $\mathrm{CO}_{2}$ under predicted magma genesis conditions and some petrological and geophysical implications, Rev. Geophys. Space Phys. 15, 351-361, 1977.

[56] Y. Bottinga and M. Javoy, Mid-ocean ridge basalt degassing: bubble nucleation, J. Geophys. Res. 95, 51255131, 1990.

[57] J.C. Duchesne, Origin and evolution of monzonorites related to anorthosites, Schweiz. Mineral. Petrogr. Mitt. 70, 189-198, 1990.

[58] J. Longhi and L.D. Ashwal, Two-stage models for lunar and terrestrial anorthosites: petrogenesis without a magma ocean, Proc. 15th Lunar Planet. Sci. Conf., Part 2 (J. Geophys. Res. 90, C571-C584, 1985). 